\title{
Antiproliferative activity of extracts prepared from three species of Reishi on cultured human normal and tumor cell lines
}

\author{
YOHTARO KATAGATA and FUMIYUKI SASAKI \\ Department of Biochemistry and Biotechnology, Faculty of Agriculture and Life Science, \\ Hirosaki University, Hirosaki, Aomori 036-8561, Japan
}

Received July 31, 2009; Accepted September 10, 2009

DOI: $10.3892 / \mathrm{mmr}$ _00000237

\begin{abstract}
The present study investigated the growth of human fibrosarcoma (HT-1080) and fibroblast (SF-TY) cells in combination with water-soluble (WS) and high molecular component (HMC) fractions prepared from Reishi (R), Rokkaku-Reishi (2R) and Apple Rokkaku-Reishi (A2R). Each WS fraction exhibited dose-and time-dependent inhibition of the growth of the HT-1080 and SF-TY cells. The extracts exhibited marked antiproliferative activity against the HT-1080 cells. The HMC fractions inhibited cell growth dose-and time-dependently in the HT-1080 cells only, and not in the SF-TY cells, suggesting that HMC fractions selectively inhibit HT-1080 cells. Among the HMC fractions, A2R is a strong candidate for anti-tumor targeting since its fraction exhibited better inhibition than the $R$ and $2 R$ fractions. Furthermore, the volume of the $A 2 R$ fraction was approximately five times greater than that of the others, and included four proteins (molecular mass 9, 13, 22 and $40 \mathrm{kDa}$ ) detected by SDS-PAGE. Three of these (13, 22 and $40 \mathrm{kDa}$ ) were confirmed to be glycosylated with the Periodic Acid-Schiff Stain kit. These results suggest that A2R may possess anti-tumor activity and, in particular, that the protein components of $\mathrm{A} 2 \mathrm{R}$ may act to selectively inhibit the growth of HT-1080 cells.
\end{abstract}

\section{Introduction}

Ganoderma lucidum (Reishi, R) is an oriental basidiomycetous fungus that has long been widely used as a medicinal mushroom in China and other eastern Asian countries, and is considered to have beneficent effects on human health. The antler-shaped fruiting body of G. lucidum, which is called

Correspondence to: Dr Yohtaro Katagata, Hirosaki University, Faculty of Agriculture and Life Science, Department of Biochemistry and Biotechnology, 3 Bunkyocyo, Hirosaki, Aomori 036-8561, Japan

E-mail: katagata@cc.hirosaki-u.ac.jp

Key words: Ganoderma lucidum (Reishi), Rokkaku-Reishi, Apple Rokkaku-Reishi, water-soluble fraction, high-molecular component fraction, glycoprotein
Rokkaku-Reishi (2R) in Japan, is a variant type of G. lucidum, and is rarely found in the wild, in a ratio of one $2 \mathrm{R}$ out of $2-3 \times 10^{5} \mathrm{R}$. Apple Rokkaku-Reishi (A2R) is produced by $2 \mathrm{R}$ spores in a medium containing fine powder made from apple-tree prunings. Numerous studies have demonstrated that G. lucidum consists mainly of numerous polysaccharides, triterpenes and lipids (1-4). These components have been demonstrated to possess anti-oxidative, anti-hypertension and anti-cancer functions. Though several studies have reported the biological activities of $2 \mathrm{R}$ extracts in vitro and in vivo, little is known regarding its molecular mechanisms, and analyses of protein and peptide components extracted from G. lucidum have never been reported in the literature. We examined the antiproliferative effects of extracts from $\mathrm{R}, 2 \mathrm{R}$ and $\mathrm{A} 2 \mathrm{R}$ on human fibrosarcoma in vitro, and compared these effects with cytotoxic effects on human fibroblasts.

\section{Materials and methods}

Preparation of water-soluble component fractions from Reishi, Rokkaku-Reishi and Apple Rokkaku-Reishi. The $\mathrm{R}$ and $2 \mathrm{R}$ powders were produced in Japan and purchased from Adaptgen Pharmaceutical Co., Ltd (Gifu, Japan). The A2R powder sample was a generous gift from Mr. H. Shibata (Co-operative of Functional Food Development Center, Aomori, Japan). Five grams of each powder were suspended in $50 \mathrm{ml}$ of distilled water and agitated at $80^{\circ} \mathrm{C}$ for $10 \mathrm{~min}$. The treated and suspended solutions were centrifuged at $12,000 \mathrm{rpm}$ at $4^{\circ} \mathrm{C}$ for $10 \mathrm{~min}$, and the supernatants obtained were lyophilized to produce water-soluble (WS) extracts. The WS extracts were treated with $80 \%$ cold acetone (final concentration) and then centrifuged at $12,000 \mathrm{rpm}$ at $4^{\circ} \mathrm{C}$ for 15 min to prepare the high molecular component (HMC) fractions. After dialyzation, the lyophilized extracts were used in the following experiments.

Cell culture. Cultured human fibrosarcoma (HT-1080) (5) and fibroblast (SF-TY) samples were supplied by the Health Science Research Resources Bank, Osaka, Japan. These cell lines were maintained in culture for no more than two weeks for each set of experiments to ensure that their phenotype would not change through prolonged in vitro passage. The cultured cells were grown as monolayers by passage at a semiconfluent stage in culture dishes $\left(78.5 \mathrm{~cm}^{2}\right.$; Greiner Bio-One 
Table I. Distribution rates of the active components in three species of Reishi.

\begin{tabular}{lcccc}
\hline & WS fraction dry weight $(\mathrm{g})$ & Percentage & HMC fraction dry weight $(\mathrm{mg})$ & Percentage \\
\hline $\mathrm{R}$ & 0.11 & 2 & 15 & 0.30 \\
$\mathrm{R}$ & 0.11 & 2 & 16 & 0.32 \\
$\mathrm{~A} 2 \mathrm{R}$ & 0.51 & 10 & 32 & 0.63 \\
\hline
\end{tabular}

For the experiments, $5 \mathrm{~g}$ dry weight of each sample was employed. R, Reishi; 2R, Rokkaku-Reishi; A2R, Apple Rokkaku-Reishi.

$\mathrm{GmbH}$, Frickenhausen, Germany) at $37^{\circ} \mathrm{C}$ in a humidified incubator with $5 \% \mathrm{CO}_{2} / 95 \%$ air. Each cell line was then plated at $\sim 1.5 \times 10^{3}$ cells $/ \mathrm{cm}^{2}$ in Dulbecco's modified essential medium (DMEM with Eagle's salt and non-essential amino acids, without L-glutamine; Gibco Co. Ltd.) containing $10 \%$ fetal calf serum (FCS), $100 \mathrm{U} / \mathrm{ml}$ penicillin, $50 \mu \mathrm{g} / \mathrm{ml}$ streptomycin, $50 \mu \mathrm{g} / \mathrm{ml}$ kanamycin and $2.5 \mu \mathrm{g} / \mathrm{ml}$ amphotericin B. Cell numbers were determined using a hematocytometer.

Cell proliferation assay. The Cell Proliferation Reagent WST-1 (4-[3-(4-iodophenyl)-2-(4-nitrophenyl)-2H-tetrazolio]-1, 3-benzene disulfonate) assay (Roche Diagnostics $\mathrm{GmbH}$, Germany) was applied according to the manufacturer's protocol. Briefly, cells $\left(5 \times 10^{3} /\right.$ well) were cultured in a 96 -well plate (Iwaki Glass Co. Ltd., Tokyo, Japan) for $12 \mathrm{~h}$ and treated at the indicated concentrations $(0.125-0.5 \mathrm{mg} / \mathrm{ml})$ (6) with each of the WS or HMC fractions prepared from G. lucidum. Proliferation was determined 6-96 $\mathrm{h}$ after the addition of the extracts according to the rate of formazan production indicated by WST-1 cleavage measured by a microplate reader at $450 \mathrm{~nm}$ (Bio-Rad Laboratories Inc., Tokyo, Japan).

Calculation of viability and statistical significance. Data represent the mean \pm SD of two separate experiments. Viability was calculated as the percentage of living cells using the formula:

$$
\text { Viability }(\%)=\frac{\text { absorbance of sample }}{\text { absorbance of control }}
$$

$S D S$ - and Tricine-SDS-PAGE. Each HMC of the three species of Reishi was treated with $2 \mathrm{X}$ SDS buffer (7) for $3 \mathrm{~min}$ at $100^{\circ} \mathrm{C}$. The treated samples were subjected to SDS-PAGE (10\% acrylamide) gel, then the gels were stained with Coomassie Brilliant Blue (CBB) R-250 or a silver staining kit. Once sufficient data were accumulated, Tricine-SDS (TS)-PAGE was conducted, then proteins on the unstained gels were electroblotted onto polyvinylidene difluoride (PVDF) membranes $(0.2 \mathrm{~mm}$; Bio-Rad Laboratories Inc., Hercules, CA, USA) at $2 \mathrm{~mA} \mathrm{~cm}^{-2}$ for $1 \mathrm{~h}$. The blotted PVDF membranes were stained with CBB G-250 or the Periodic Acid Schiff (PAS) Stain kit. TS-PAGE procedures were performed according to Schägger and Jagow (8). Stacking (4\% T; $0.25 \% \mathrm{C})$, spacer $(10 \% \mathrm{~T} ; 0.6 \% \mathrm{C})$ and separating $(18 \% \mathrm{~T} ; 2.2 \% \mathrm{C})$ gels were prepared according to the method described by Schägger (9), where $\mathrm{T}$ denotes the total percentage of the concentration of both monomers (acrylamide and bisacrylamide) and $\mathrm{C}$ the percentage of the concentration of the crosslinker relative to the total concentra- tion T. The employed sample was separated using two buffer systems: anode buffer containing Tris- $\mathrm{HCl}$ and cathode buffer containing Tris and TS. The gel was subjected to a constant voltage of $30 \mathrm{~V}$ until the application of CBB tracking dye (G-250; Fluka, Buchs, Switzerland) ( 1 h), then the voltage was raised to $60 \mathrm{~V}$ until the tracking dye entered the separating gel. After electrophoresis, the gels were stained with CBB G-250 in a methanol-acetic acid-water solution (45:10:45 $\mathrm{v} / \mathrm{v} / \mathrm{v}$ ) for $1 \mathrm{~h}$, and de-stained with methanol-acetic acid-water (20:7:73 v/v/v). In addition, when necessary, silver staining was conducted using the Dodeca Silver Stain kit (Bio-Rad Laboratories Inc.) according to the manufacturer's protocol. To examine whether the proteins were glycosylated or not, the electroblotted membranes of the gels were treated using the GelCode Glycoprotein Staining kit (Pierce Biotechnology Inc., Rockford, IL, USA) according to the manufacturer's protocol.

\section{Results}

Water-soluble and high molecular component fractions of the three species of Reishi. Each WS fraction was produced from the three species of Reishi with an initial dry weight of $5 \mathrm{~g}$ as follows: R, $0.11 \mathrm{~g} \mathrm{(2 \% );} \mathrm{2R,} 0.11 \mathrm{~g} \mathrm{(2 \% );} \mathrm{A2R,} 0.51 \mathrm{~g}(10 \%)$. The volume of the A2R WS fraction was approximately five times greater than that of the $\mathrm{R}$ and $2 \mathrm{R}$ fractions. Acetone precipitation was conducted for each WS fraction with cold $80 \%$ acetone. The HMCs obtained accounted for $\sim 13.6,14.5$ and $62.7 \%$ of their respective WS fractions; the HMC of A2R was approximately five times as great as that of the $R$ and $2 R$ WS fractions (Table I).

Inhibitory effect on cell proliferation by the water-soluble and high molecular component fractions. Cultured human HT-1080 and SF-TY cells were each treated with $0-0.5 \mathrm{mg} / \mathrm{ml}$ of the WS fraction prepared from the three species of Reishi. In the HT-1080 cells, cell proliferation was decreased at $24 \mathrm{~h}$ following the addition of each WS fraction compared with the control fraction (Fig. 1A-C). This inhibition was dependent on the concentration of each WS fraction. By contrast, in the SF-TY cells, though the cell growth levels were dependent on the WS fraction concentration used, the suppression of cell growth was not observed (Fig. 1D-F).

Cell viability was calculated according to the formula described in Materials and methods, and the effects of the three WS fractions $(0.5 \mathrm{mg} / \mathrm{ml}$ respectively) on the HT-1080 and SF-TY cells are presented in Table II. The R and R2 WS fractions inhibited cell viability by $50-60 \%$ in the HT-1080 cells at $6 \mathrm{~h}$ following the addition of the extracts. At $96 \mathrm{~h}$ 

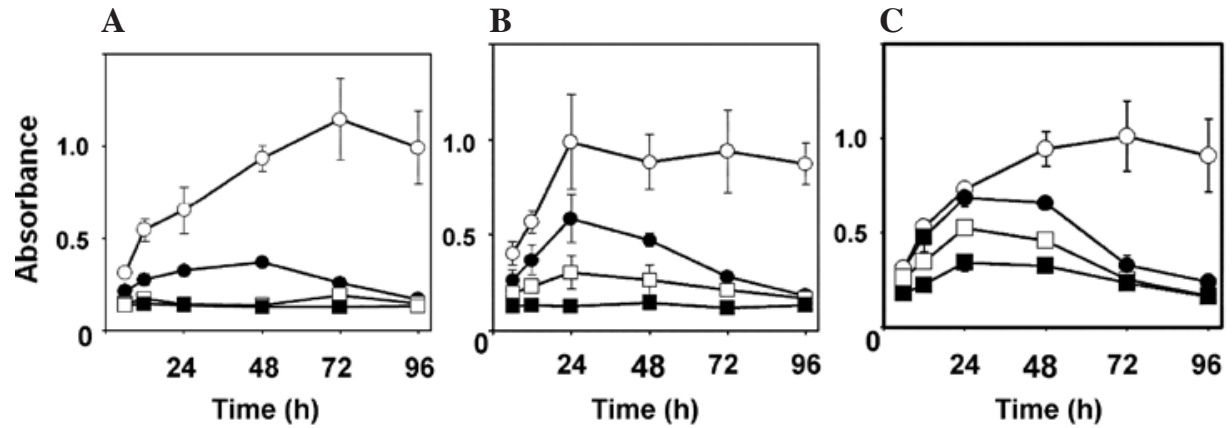

D

$\mathbf{E}$

F
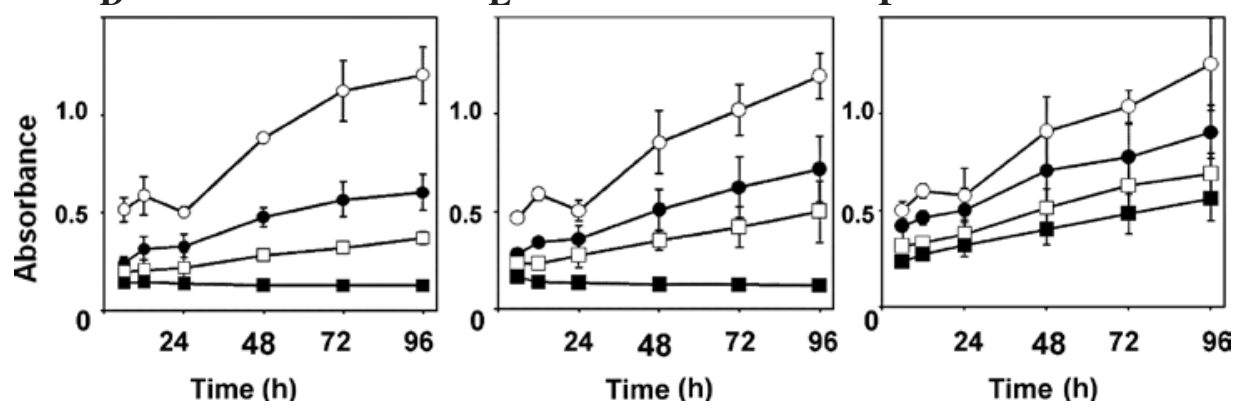

Figure 1. Time-and dose-dependent inhibitory effects on proliferation in human fibrosarcoma and fibroblast cell lines by water-soluble (WS) fractions prepared from three species of G. lucidum. HT-1080 (A-C) and SF-TY (D-F) cells were treated with $0(0), 0.125(\bullet), 0.25$ ( $\square$ ) and 0.5 ( $\square$ ) mg/ml of WS fractions from Reishi (A and D), Rokkaku-Reishi (B and E) and Apple Rokkaku-Reishi (C and F). Proliferation was assessed at 6, 12, 24, 48, 72 and 96 h. Each bar represents the mean $\pm \mathrm{SD}$ of triplicate data points from two separate experiments.

Table II. Cell proliferation inhibition rates by WS fractions prepared from R, 2R and A2R in the HT-1080 and SF-TY cell lines.

\begin{tabular}{|c|c|c|c|c|c|c|}
\hline & $6 \mathrm{~h}$ & $12 \mathrm{~h}$ & $24 \mathrm{~h}$ & $48 \mathrm{~h}$ & $72 \mathrm{~h}$ & $96 \mathrm{~h}$ \\
\hline \multicolumn{7}{|c|}{ HT-1080 } \\
\hline $\mathrm{R}$ & 0.563 & 0.729 & 0.792 & 0.860 & 0.886 & 0.864 \\
\hline $2 \mathrm{R}$ & 0.686 & 0.765 & 0.869 & 0.837 & 0.871 & 0.849 \\
\hline A2R & 0.399 & 0.570 & 0.534 & 0.656 & 0.767 & 0.819 \\
\hline \multicolumn{7}{|l|}{ SF-TY } \\
\hline $\mathrm{R}$ & 0.722 & 0.753 & 0.728 & 0.856 & 0.885 & 0.893 \\
\hline $2 \mathrm{R}$ & 0.654 & 0.765 & 0.737 & 0.855 & 0.878 & 0.899 \\
\hline A2R & 0.535 & 0.548 & 0.445 & 0.559 & 0.537 & 0.556 \\
\hline
\end{tabular}

R, Reishi; 2R, Rokkaku-Reishi; A2R, Apple Rokkaku-Reishi; HT-1080, fibrosarcoma cells, SF-TY, fibroblast cells. For the experiments, $0.5 \mathrm{mg} / \mathrm{ml}$ WS fraction was employed.

after the extracts were added, the percentage of inhibition was found to be $\sim 85 \%$. A2R showed inhibition of only $\sim 40 \%$ at $6 \mathrm{~h}$, but that percentage slowly increased to $\sim 82 \%$ at $96 \mathrm{~h}$, an inhibition percentage value almost identical to that of $\mathrm{R}$ and $\mathrm{R} 2$. In the SF-TY cells, inhibition rates (cell growth disorder) of $\mathrm{R}$ and $2 \mathrm{R}$ were $65-72 \%$ at $6 \mathrm{~h}$ following the addition of the WS fraction, and increased to $\sim 90 \%$ at $96 \mathrm{~h}$. The effect of A2R was almost constant from the first (6 h) to the final (96 h) measurement (Table II).

The HMC fractions of the three species of Reishi prepared with acetone precipitation were examined for their effects on proliferation in the HT-1080 and SF-TY cells by the same procedures as those used for the WS fractions. In the HT-1080 cells, the HMC fractions yielded almost identical results to the WS fractions, and marked time- and dose-dependent inhibi- tion was observed for the HMC fraction of A2R (Fig. 2A-C). No time-and dose-dependent inhibition of proliferation was observed in the SF-TY cell line (Fig. 2D-F).

Characterization of high molecular component in Apple Rokkaku-Reishi. SDS-PAGE containing $12.5 \%$ acrylamide and TS-PAGE were conducted as described in Materials and methods. No protein bands were observed in the $\mathrm{R}$ and 2R HMC fractions, even using silver staining procedures. However, A2R possessed three main bands, estimated to have a molecular mass of 9,13 and $22 \mathrm{kDa}$, respectively (Fig. 3A). Each protein $(10 \mu \mathrm{g})$ was applied to the gel. The PVDF blotting membranes were stained with PAS whether or not the protein bands were glycosylated (Fig. 3B) (10). Only two bands (13 and $22 \mathrm{kDa}$ ) of the A2R HMC fraction 

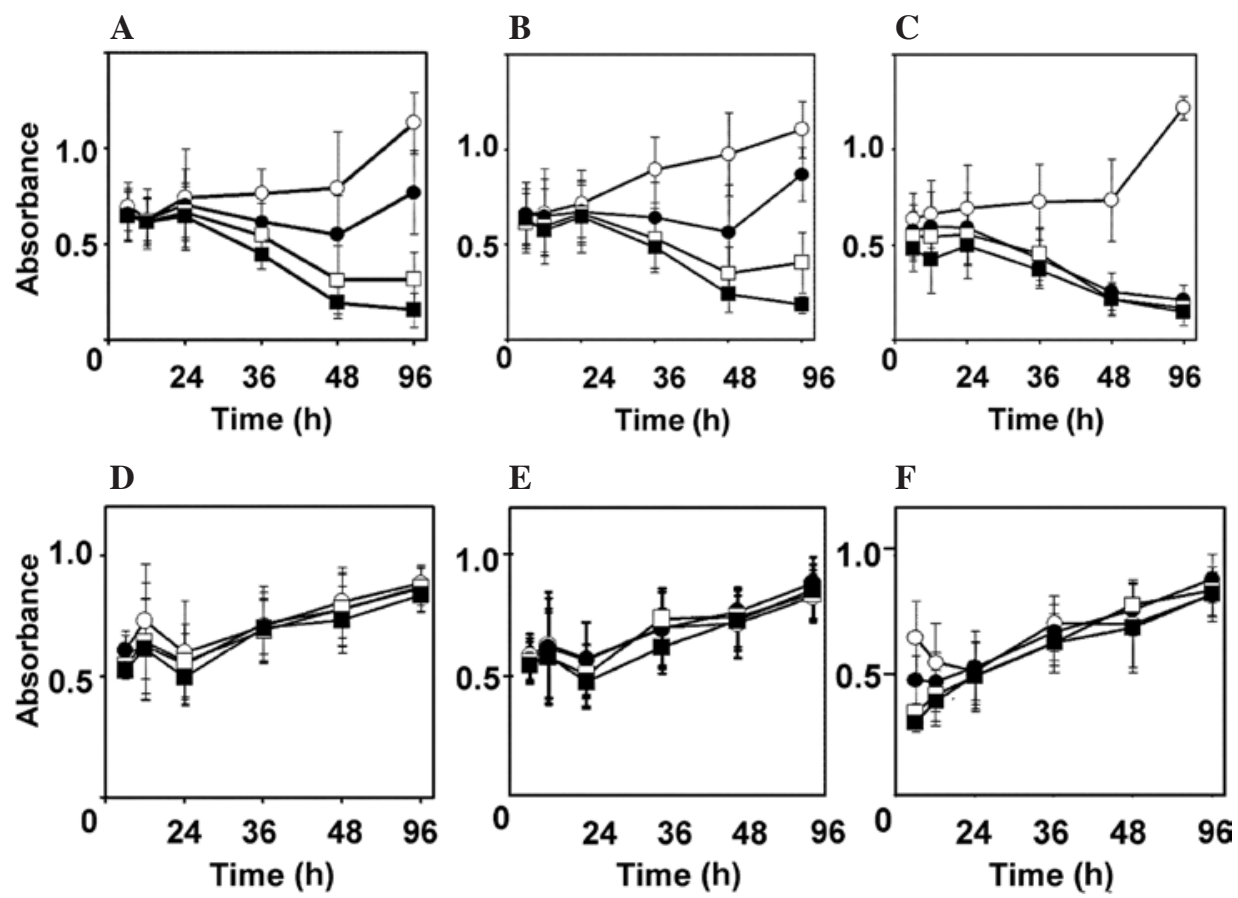

Figure 2. Time-and dose-dependent inhibitory effects on proliferation in human fibrosarcoma and fibroblast cell lines by high molecular complex (HMC) fractions prepared from three species of G. lucidum. HT-1080 (A-C) and SF-TY (D-F) cells were treated with $0(0), 0.125(\bullet), 0.25(\square)$ and $0.5(\square)$ mg/ml of HMC fractions from Reishi (A and D), Rokkaku-Reishi (B and E) and Apple Rokkaku-Reishi (C and F). Proliferation was assessed at 6, 12, 24, 48, 72 and 96 h. Each bar represents the mean \pm SD of triplicate data points from two separate experiments.
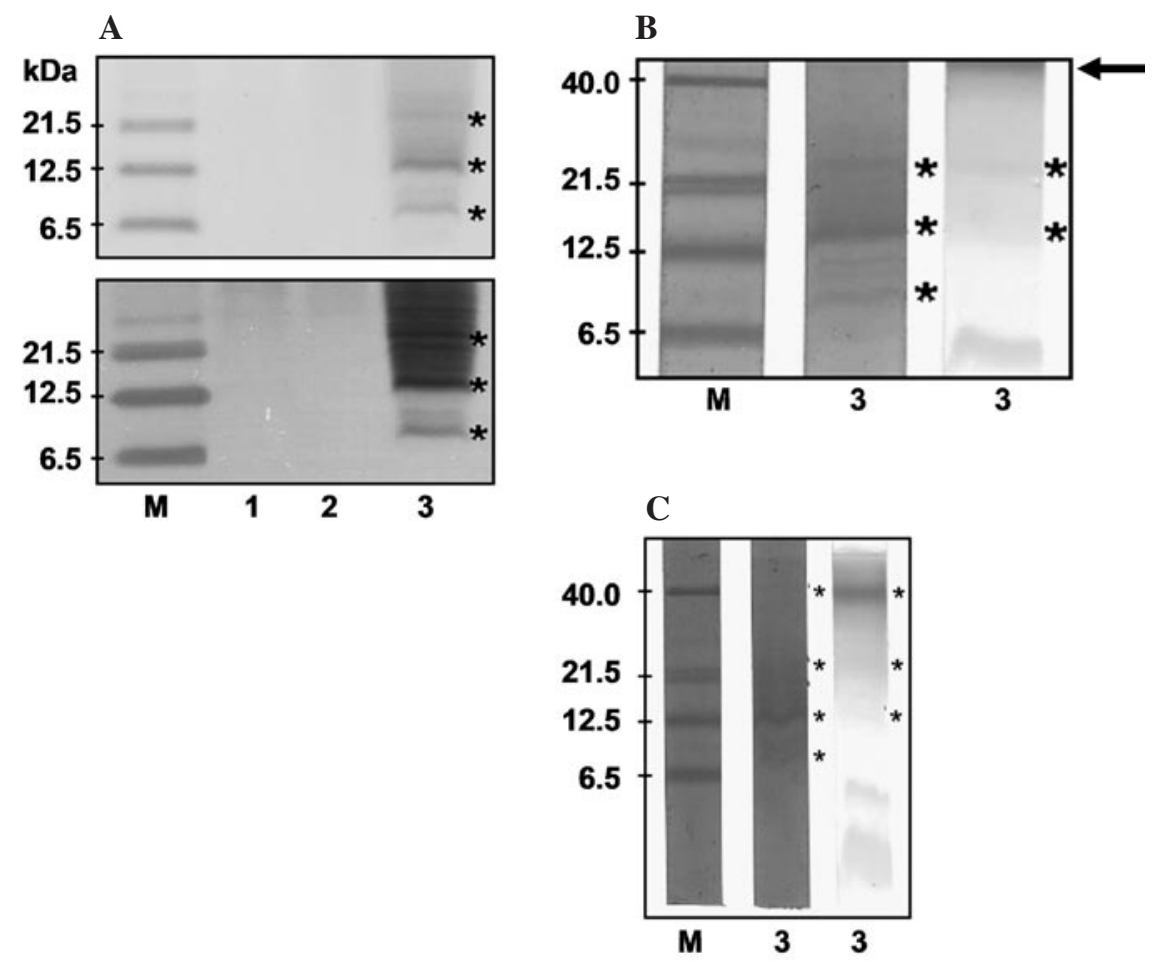

Figure 3. Detection of major protein constituents in HMC fractions of Reishi (R), Rokkaku-Reishi (2R) and Apple Rokkaku-Reishi (A2R). (A) Coomassie Brilliant Blue R-250 and silver stainings using SDS-PAGE. (B) CBB G-250 and PAS staining using Tricine-SDS-PAGE. (C) CBB G-250 PAS staining using Tricine-SDS-PAGE without spacer gel. "Major or glycosylated proteins; arrow, uncertain band; 1, R; 2, 2R; and 3, A2R HMC fractions; M, molecular marker.

were determined to be glycosylated. An indistinct band was observed at $\sim 40 \mathrm{kDa}$ (Fig. 3B, arrow). Therefore, TS-PAGE was conducted without spacer gel (Fig. 3C) and the $\sim 40-\mathrm{kDa}$ band was also confirmed to be glycosylated.
Comparison of cell viability in HT-1080 cells with the watersoluble and high molecular component fractions of $A 2 R$. The percentage of cell viability was calculated using the formula described in Materials and methods, and the effect of the 
A

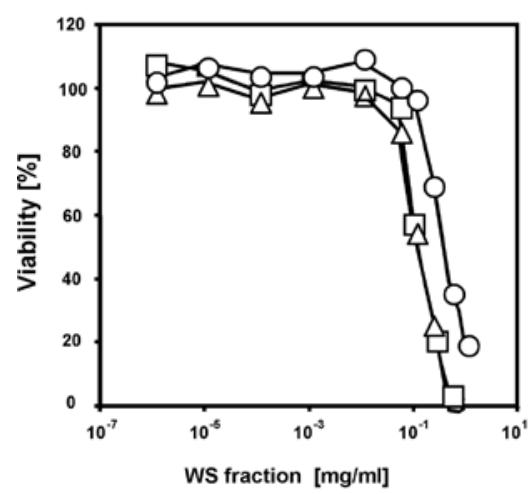

B

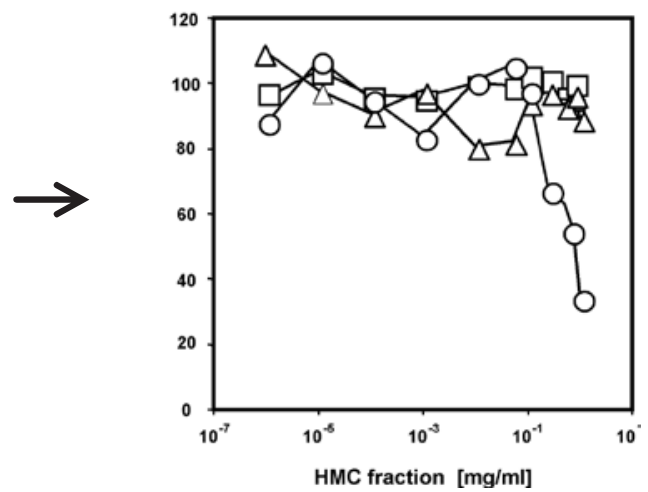

Figure 4. Comparison of cell viability of fibrosarcoma cells with the WS and HMC fractions. $\square$, Reishi; $\triangle$, Rokkaku-Reishi; ○, Apple Rokkaku-Reishi.

WS and HMC fractions on HT-1080 cells was determined. Cell viability in cells treated with each WS fraction showed an almost identical transition; however, the HMC fraction of A2R suppressed cell viability at a high concentration (Fig. 4). $\mathrm{R}$ and $2 \mathrm{R}$ exhibited no change in cell viability independent of concentration in either the WS or HMC fractions.

\section{Discussion}

Ganoderma lucidum is a well-known traditional Chinese medicinal fungus that has been used for several thousand years in China, Japan and other Asian countries. The major active components of $G$. lucidum include triterpenoids $(1,2)$, polysaccharides (3), lipids (4) and active low-molecular-mass $\beta$-glucan (11). Recently, in a thorough and detailed review, Paterson (12) investigated the antiproliferative effects on tumorigenic cells and the protein chemical characteristics of WS and HMC extracts from three species of Reishi (R, 2R and A2R). The effects of G. lucidum extracts on tumorigenesis and metastasis in a cultured human tumor cell line have also been examined (13-17).

In the present study, WS and HMC fractions prepared from three species of Reishi (each sample $5 \mathrm{~g}$ dry weight) were examined (Table I). The components of A2R were approximately five and two times greater, respectively, than those of $\mathrm{R}$ and $2 \mathrm{R}$. To examine the effects of WS and HMC fractions prepared from $\mathrm{R}, 2 \mathrm{R}$ and $\mathrm{A} 2 \mathrm{R}$ on cell proliferation, the HT-1080 (fibrosarcoma) and SF-TY (fibroblast) cell lines were treated with WS or HMC fractions in controlled dose and time experiments. As presented in Fig. 1, the three WS fractions inhibited cell proliferation in HT-1080 cells in a time-and dose-dependent manner. However, in SF-TY cells, only a slight dose-dependent level $(0.5 \mathrm{ml} / \mathrm{ml})$ of inhibition was sustained. To further elucidate cell viability with the WS fraction, viability percentage (inhibition rate) was calculated using the formula described in Materials and methods. From the time of addition, the WS fractions of $\mathrm{R}$ and $2 \mathrm{R}$ showed strong inhibition activities on HT-1080 cells of 56 and 69\%, respectively (Table II). By contrast, the inhibition rate of $\mathrm{A} 2 \mathrm{R}$ was $\sim 40 \%$ at $6 \mathrm{~h}$ after the addition of $\mathrm{A} 2 \mathrm{R}$, but reached a final value of $\sim 82 \%$ at $96 \mathrm{~h}$, almost identical to the values of $\mathrm{R}$ $(87 \%)$ and $2 \mathrm{R}(85 \%)$ at the same time point. This suggests that R and $2 \mathrm{R}$ WS fractions may have an immediate effect and barrier function on HT-1080 cell growth. Compared to R and $2 \mathrm{R}, \mathrm{A} 2 \mathrm{R}$ initially showed mild and weak effects. However, an almost identical inhibition rate was achieved at $96 \mathrm{~h}$ after the addition of extract in the HT-1080 cells. Moreover, the A2R fraction was constant and further inhibited the SF-TY cells compared with the other fractions. These data suggest that the WS fraction prepared from A2R reduces cytotoxic effects more than the other Reishi fractions.

To elucidate which components of the WS fractions affected cell viability, HMCs were prepared from each WS fraction to eliminate various low-molecular-mass peptides, polyphenols and polysaccharides using acetone precipitation and lyophilization. However, the WST-1 assay revealed that the HMC fractions had almost identical tendencies as the WS fractions shown in Fig. 2. However, compared with $\mathrm{R}$ and $2 \mathrm{R}$ (Fig. 2A and B) the HMC fraction of A2R displayed distinctive cell growth inhibition activity (Fig. 2C) in HT-1080 cells. On the other hand, none of the HMC fractions had an effect on cell growth in the SF-TY cell line. These data show that highmolecular-mass substances in HMC fractions did not suppress normal cell growth (Fig. 2D-F), indicating that G. lucidum has potential therapeutic effects. Based on SDS-PAGE (Fig. 3A) (10 $\mu \mathrm{g}$ used, respectively), only the WS fraction of A2R had three bands of $\sim 6.5,13$ and $22 \mathrm{kDa}$. Silver staining revealed no bands, suggesting that high-molecular-mass proteins may be absent or present at only extremely low levels in WS fractions of $\mathrm{R}$ and $2 \mathrm{R}$. To further analyze the HMC components with high resolution, TS-PAGE, which effectively elucidates low-molecular-mass substances (10-40 kDa), was conducted. As shown in Fig. 3B, the HMC fraction of A2R comprised two bands (13 and $22 \mathrm{kDa}$ ), confirmed to be glycosylated by PAS staining. Since additional ambiguities were detected (Fig. 3B, arrow), further TS-PAGE was conducted without spacer gel. Fig. 3C shows that the $40-\mathrm{kDa}$ band was also glycosylated. Therefore, three bands $(13,22$ and $40 \mathrm{kDa})$ of the four were glycosylated in the A2R HMC fraction. Although TS-PAGE requires more complicated handling than SDS-PAGE, acceptable results were obtained (Fig. 3). This is the first report on the presence of these proteins in any of the three species of Reishi.

This experiment also ascertained the selective effects had on HT-1080 cells. The loss of low-molecular-mass peptides by lyophilization may be related to the suppression of proliferation in HT-1080 cells with the R and 2R extracts (Fig. 4A and 
B). As shown in Fig. 4, only the A2R extract had no effect on the viability of HT-1080 before and after lyophilization, which suggests that a high-molecular-mass component of A2R may be suppressed for the proliferation of HT-1080 cells, and that a definite amount of the low-molecular-mass component may be necessary for the phenomena in tumorigenic cells described above. The high-molecular-mass component in A2R extract may have a lasting suppressive effect on tumorigenic cell growth (Table II and Fig. 4). Moreover, as shown in Table II, the quantitative combination of low- and high-molecular-mass components in A2R may be necessary for antiprolifelative activity, though it may cause mild damage to normal cells.

\section{Acknowledgements}

This work was supported in part by funds for the Promotion of International Scientific Research (Y.K. 2006-C-1, 2007-C-1) and the 'Go Go fund in Hirosaki Univ.' (Y.K. 2007).

\section{References}

1. Lin SB, Li CH, Lee SS and Kan LS: Triterpene-enriched extracts from Ganoderuma lucidum inhibit growth of hepatoma cells via suppressing protein kinase $\mathrm{C}$, activating mitogen-activated protein kinases and G2-phase cell cycle arrest. Life Sci 72: 2381-2390, 2003 .

2. Kimura Y, Taniguchi M and Baba K: Antitumor and antimetastatic effects on liver of triterpenoid fractions of ganoderuma lucidum: mechanism of action and isolation of an active substance. Anticancer Res 22: 3309-3318, 2002.

3. Wang YY, Khoo KH, Chen ST, Lin CC, Wong CH and Lin CH: Studies on the immuno-modulating and antitumor activities of Ganoderma lucidum (Reishi) polysaccharides: functional and proteomic analyses of a fucose-containing glycoprotein fraction responsible for the activities. Bioorganic and Medicinal Chem 10: 1057-1062, 2002

4. Liu X, Yuan JP, Chung CK and Chen XJ: Antitumor activity of the sporoderum-broken germinating spores of Ganoderuma lucidum. Cancer Lett 182: 155-161, 2002.
5. Rasheed S, Nelson-Rees WA, Toth EM, Arnstein P and Gardner MB: Characterization of a newly derived human sarcoma cell line (HT-1080). Cancer 33: 1027-1033, 1974.

6. Bradford MM: A rapid and sensitive method for the quantitation of microgram quantities of protein utilizing the principle of protein-dye binding. Anal Biochem 72: 248-254, 1976.

7. Laemmli UK: Cleavage of structural proteins during the assembly of the head bacteriophage T4. Nature 227: 680-688, 1970.

8. Schägger H and Jagow G: Tricine-sodium dodecyl sulfate-polyacrylamide gel electrophoresis for the separation of protein in the range from 1 to $100 \mathrm{kDa}$. Anal Biochem 106: 368-379, 1987.

9. Schägger $\mathrm{H}$ : Tricine-SDS-PAGE. Nature protocols 1: 16-22, 2006.

10. Katagata Y and Hirayama T: Unexpected expression of Hsp47, a replacement of one amino acid (Val $7 \mathrm{Leu}$ ) in the amino terminal region, in cultured human tumorigenic cell lines. J Dermatol Sci 49: 33-38, 2008.

11. Kimura Y, Sumiyoshi M, Suzuki T and Sakanaka M: Antitumor and antimetastatic activity of a novel water-soluble low molecular weight $\beta$-1,3-glucan (branch $\beta-1,6$ ) isolated from Aureobasidium pullulans 1A1 strain black yeast. Anticancer Res 26: 4131-4141, 2006.

12. Paterson RR: Ganoderuma - a therapeutic fungal biofactory. Phytochemistry 67: 1985-2001, 2006.

13. Liu YW, Gao JL, Guan J, Qian ZM, Feng K and Li SP: Evaluation of antiproliferative activities and action mechanisms of extracts from two species of Ganoderuma on tumor cell lines. J Agri Food Chem 57: 3087-3093, 2009.

14. Weng CJ, Chau CF, Yen GC, Liao JW, Chen DH and Chen KD: Inhibitory effects of Ganoderuma lucidum on tumorigenesis and metastasis of human hepatoma cells in cells and animal models. J Agri Food Chem 57: 5049-5057, 2009.

15. Cao Q and Lin ZB: Ganoderuma lucidum polysaccharides peptide inhibits the growth of vascular endothelial cell and the induction of VEGF in human lung cancer cell. Life Sci 78: 1457$1463,2006$.

16. Chang UM, Li CH, Lin LI, Huang CP, Kan LS and Lin SB: Ganoderiol F, a ganoderma triterpene, induces senescence in hepatoma HepG2 cells. Life Sci 79: 1129-1139, 2006.

17. Tang W, Liu JW, Zhao WM, We DZ and Zhong JJ: Ganoderic acid T from Ganoderma lucidum mycelia induces mitochondria mediated apoptosis in lung cancer cells. Life Sci 80: 205-211, 2006. 